\title{
Fossil Locations and Data for the Taylor Mountains, and Parts of the Bethel, Goodnews, and Dillingham Quadrangles, Southwestern Alaska
}

Open-File Report 2011-1065 



\section{Fossil Locations and Data for the Taylor Mountains, and Parts of the Bethel, Goodnews, and Dillingham Quadrangles, Southwestern Alaska}

By S.M. Karl, R.B. Blodgett, K.A. Labay, S.E. Box, D.C. Bradley, M.L. Miller, W.K. Wallace, University of Alaska, Fairbanks, and J.F. Baichtal, U.S. Forest Service

Open-File Report 2011-1065 


\title{
U.S. Department of the Interior \\ KEN SALAZAR, Secretary \\ U.S. Geological Survey \\ Marcia K. McNutt, Director
}

\author{
U.S. Geological Survey, Reston, Virginia: 2011
}

For more information on the USGS - the Federal source for science about the Earth, its natural and living resources, natural hazards, and the environment, visit http://www.usgs.gov or call 1-888-ASK-USGS.

For an overview of USGS information products, including maps, imagery, and publications, visit http://www.usgs.gov/pubprod

To order this and other USGS information products, visit http://store.usgs.gov

Any use of trade, product, or firm names is for descriptive purposes only and does not imply endorsement by the U.S. Government.

Although this report is in the public domain, permission must be secured from the individual copyright owners to reproduce any copyrighted materials contained within this report.

Suggested citation:

Karl, S.M., Blodgett, R.B., Labay, K.A., Box, S.E., Bradley, D.C., Miller, M.L., Wallace, W.K., and Baichtal, J.F., 2011, Fossil locations and data for the Taylor Mountains, and parts of the Bethel, Goodnews, and Dillingham quadrangles, southwestern Alaska: U.S. Geological Survey Open-File Report 2011-1065, 2 p. 


\section{Contents}

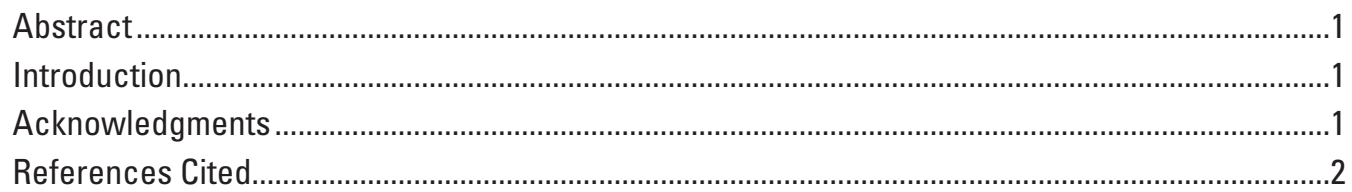

\section{Plate}

Plate 1. Fossil locations in the Taylor Mountains, and parts of the Bethel, Goodnews Bay, and Dillingham quadrangles, Alaska.

\section{Table}

Table 1. Fossil data for the Taylor Mountains, and parts of the Bethel, Goodnews, and Dillingham quadrangles, Alaska.

\section{Conversion Factors and Datums}

Conversion Factors

\begin{tabular}{lcc}
\hline & Bultiply & To obtain \\
\hline mile $(\mathrm{mi})$ & Length & \\
\hline
\end{tabular}

Datums

Horizontal coordinate information is referenced to the North American Datum of 1927 (NAD 27). 
This page intentionally left blank. 


\title{
Fossil Locations and Data for the Taylor Mountains, and Parts of the Bethel, Goodnews, and Dillingham Quadrangles, Southwestern Alaska
}

\author{
By S.M. Karl, R.B. Blodgett, K.A. Labay, S.E. Box, D.C. Bradley, M.L. Miller, W.K. Wallace', and J.F. Baichtal²
}

\section{Abstract}

Information about fossils collected by U.S. Geological Survey, State of Alaska, academic, and industry geologists that have been reported in literature or archived in reports from the former U.S. Geological Survey Branch of Paleontology and Stratigraphy are compiled on a plate and table in this report to provide comprehensive paleontologic age data for the Taylor Mountains quadrangle area in southwestern Alaska. The reports used to compile the table in this report were submitted by recognized paleontologic experts. Some of the information is derived from reports that date back almost 100 years. Many of the data are available in more detail in the Alaska Paleontological Database (http://www.alaskafossil.org/). The 287 entries in this table are shown on the accompanying plate, on which symbols representing the entries are color-coded by geologic age. This report represents the most comprehensive and most recently updated compilation of paleontologic data for this area.

\section{Introduction}

This fossil table (table 1) and map (plate 1) include all locations of megafossils and microfossils collected by geologists since the 1930s (Mertie, 1938). Information compiled for this report is from published geologic journal articles, the Alaska Paleontologic Database (http://www. alaskafossil.org/), and unpublished fossil reports at the U.S. Geological Survey, for the Taylor Mountains and northern
Tikchik Lakes map area. The archived reports are unpublished, although many of these reports have been quoted in detail in the Alaska Paleontological Database (http://www.alaskafossil. org/). In some cases, the data for a particular table entry are not complete; localities that yielded visible but unidentifiable fossil debris are listed because they represent potential sites for future fossil collections. Reports of nondiagnostic or poorly preserved fossils are included because additional fossils may be present at the locality and future collectors might recover more diagnostic and better-preserved specimens. Limestone samples that were collected for possible microfossils such as conodonts but did not yield fossils are not included. Fossil locations have been checked against original field maps, and if there are discrepancies in coordinate information, locations on this map should be considered as corrections of the location information in the Alaska Paleontologic Database (http:// www.alaskafossil.org/). Plate 1 includes fossil localities that overlap two related and coordinated geologic maps that are in preparation for the Tikchik Lakes area, at a scale of 1:63,360 (Karl and others, unpub. data, 2011), and for the Taylor Mountains quadrangle, at a scale of 1:250,000 (Miller and others, unpub. data, 2011).

\section{Acknowledgments}

We would like to thank reviewers Chad Hults of the U.S. Geological Survey and Jim Clough of the Alaska Division of Geological \& Geophysical Surveys for constructive suggestions that contributed to improving this report.

\footnotetext{
${ }^{1}$ University of Alaska, Fairbanks

${ }^{2}$ U.S. Forest Service
} 


\section{References Cited}

Adrain, J.M., Chatterton, B.D.E., and Blodgett, R.B., 1995, Silurian trilobites from southwestern Alaska: Journal of Paleontology, v. 69, no. 4, p. 723-736.

Alaska Paleontologic Database; http://www.alaskafossil.org/.

Blodgett, R.B., and Wilson, F.H., 2001, Reconnaissance geology north of the Hoholitna River, Taylor Mountains D-1 1:63,360-scale quadrangle, southwestern Alaska, in Gough. L.P., and Wilson, F.H., eds., Geologic studies in Alaska by the U.S. Geological Survey, 1999: U.S. Geological Survey Professional Paper 1633, p. 1-10.

Cady, W.M., Wallace, R.E., Hoare, J.M., and Webber, E.J., 1955, The central Kuskokwim region, Alaska: U.S. Geological Survey Professional Paper 268, 5 pls.

Elder, W.P., and Box, S.E., 1992, Late Cretaceous inoceramid bivalves of the Kuskokwim basin, southwestern Alaska, and their implications for basin evolution: The Paleontological Society Memoir 26, 41 p.

Elder, W.P., and Miller, J.W., 1991, Maps showing fossil localities and checklists of Jurassic and Cretaceous macrofauna of western Alaska: U.S. Geological Survey Open-File Report 91-629, 71 p., 7 sheets, scale 1:500,000.

Epstein, A.G., Epstein, J.B., and Harris, L.D., 1977, Conodont color alteration- an index to organic metamorphism: U.S. Geological Survey Professional Paper 995, 27 p.
Hoare, J.M., and Coonrad, W.L., 1978, Geologic map of the Goodnews and Hagemeister Island region, southwestern Alaska: U.S. Geological Survey Open-File Report 78-9-B, scale 1:250,000.

Hoare, J.M., and Jones, D.L., 1981, Lower Paleozoic radiolarian chert and associated rocks in the Tikchik Lakes area, southwestern Alaska, in Albert, N.R.D., and Hudson, Travis, eds., The United States Geological Survey in Alaska-Accomplishments during 1979: U.S. Geological Survey Circular 823-B, p. B44-B45.

McRoberts, C.A., and Blodgett, R.B., 2002, Late Triassic (Norian) mollusks from the Taylor Mountains quadrangle, southwestern Alaska, in Wilson, F.H., and Galloway, J.P., eds., Studies by the U.S. Geological Survey in Alaska, 2000: U.S. Geological Survey Professional Paper 1662, p. 55-67.

Mertie, J.B., Jr., 1938, The Nushagak District, Alaska: U.S. Geological Survey Bulletin 903, 96 p.

Rigby, J.K., Nitecki, M.H., Soja, C.M., and Blodgett, R.B., 1994, Silurian aphrosalpingid sphinctozoans from Alaska and Russia: Acta Palaeontologica Polonica, v. 39, p. 341391.

Silberling, N.J., Grant-Mackie, J.A., and Nichols, K.M., 1997, The Late Triassic bivalve Monotis in accreted terranes of Alaska: U.S. Geological Survey Bulletin 2151, 21 p. 
Publishing support provided by the U.S. Geological Survey Publishing Network, Tacoma Publishing Service Center

For more information concerning the research in this report, contact the Director, Alaska Science Center

U.S. Geological Survey

4210 University Drive

Anchorage, Alaska 99508

http://alaska.usgs.gov 
